Maciej Rudnicki

Katolicki Uniwersytet Lubelski Jana Pawła II

Kamila Sobieraj

Katolicki Uniwersytet Lubelski Jana Pawła II

\title{
OBECNE I PROJEKTOWANE MECHANIZMY WSPARCIA UMOŻLIWIAJĄCE REDUKCJĘ KOSZTÓW ENERGII W PRZEMYŚLE ENERGOCHŁONNYM W KONTEKŚCIE FUNKCJONOWANIA SYSTEMU HANDLU UPRAWNIENIAMI DO EMISJI
}

\section{Wprowadzenie}

Przyjęta dnia 23 kwietnia 2009 r. dyrektywa 2009/29/WE zmieniająca dyrektywę 2003/87/WE $\mathrm{WE}^{1}$ ma usprawnić i rozszerzyć wspólnotowy system handlu uprawnieniami do emisji gazów cieplarnianych (dalej także jako: system EU ETS). Niewątpliwie najistotniejszą zmianą wprowadzoną do nowego systemu EU ETS jest stopniowe odejście od bezpłatnego przydziału uprawnień na rzecz obowiązku ich zakupu na aukcjach. ${ }^{2}$ Realizacja tego obowiązku może jednak doprowadzić do znaczącego wzrostu kosztów produkcji energii, a w konsekwencji wzrostu kosztów zakupu energii elektrycznej wykorzystywanej do procesów produkcyjnych. Omawiany obowiązek zakupu uprawnień emisyjnych na aukcji przez przedsiębiorcę działającego w obszarze UE, prowadzący do znaczącego wzrostu kosztów produkcji, może spowodować z kolei duże dysproporcje cenowe między producentami z UE i producentami spoza UE nieobjętymi podobnymi ograniczeniami i stosującymi „brudne” technologie. Wpłynąć może także na utratę konkurencyjności niektórych sektorów przemysłowych (zwłaszcza tych energochłonnych) działających

Dyrektywa Parlamentu Europejskiego i Rady 2009/29/WE z dnia 23 kwietnia 2009 r. zmieniająca dyrektywę 2003/87/WE w celu usprawnienia i rozszerzenia wspólnotowego systemu handlu uprawnieniami do emisji gazów cieplarnianych (Dz.Urz. UE L 140/63 z dnia 05.06.2009 r.).

2 Por. J. Baran, A. Janik, A. Ryszko, Handel emisjami w teorii i praktyce, Warszawa 2011, s. 103. 
w obszarze UE. Taka sytuacja może być przyczyną zastąpienia produkcji w UE importem $z$ krajów trzecich bądź przenoszenia produkcji poza UE. ${ }^{3}$

Koszty pośrednie wynikają z konieczności zakupu energii elektrycznej przez przedsiębiorców działających w sektorach przemysłu od jej wytwórców. Koszty zakupu uprawnień ponoszone przez wytwórców energii mogą bowiem zostać częściowo lub w całości wliczone do cen energii elektrycznej i w ten sposób przerzucone na odbiorców końcowych. Dla sektorów przemysłu o dużej energochłonności funkcjonujących na rynku unijnym koszty energii mogą okazać się zbyt wysokie do zaakceptowania. ${ }^{4}$ Utrata konkurencyjności względem producentów z krajów trzecich może zmusić takie przedsiębiorstwa do radykalnych kroków i przeniesienia produkcji poza obszar UE. W przypadku, gdy przedsiębiorstwa przeniosą swoją produkcję poza UE, ponieważ nie będą mogły przenieść wzrostu kosztów wynikających z funkcjonowania systemu EU ETS na swoich klientów, nie tracąc przy tym znaczącego udziału w rynku, dojść może (wbrew założeniom i celom dyrektywy 2003/87/ WE $^{5}$ (zmienionej przez dyrektywę 2009/29/WE) do faktycznego zwiększenia się całkowitej emisji gazów cieplarnianych. ${ }^{6}$

Celem podjęcia tematyki zaprezentowanej $\mathrm{w}$ niniejszym opracowaniu jest analiza krajowych regulacji prawnych w zakresie obowiązujących, jak i projektowanych mechanizmów wsparcia umożliwiających redukcję kosztów energii w przemyśle energochłonnym. Podkreślić bowiem trzeba, że obciążenia wynikające z funkcjonowania trzeciej fazy systemu EU ETS będą dla polskiego przemysłu rosnące z każdym kolejnym rokiem. Szeroko zakrojone wsparcie dla rodzimego przemysłu, zwłaszcza w czasach recesji gospodarczej, na pewno może przyczynić się do wzrostu konkurencyjności przedsiębiorstw w skali UE, jak i poza UE. Z kolei brak odpowiedniego wsparcia przez państwo w szczególności dla tych branż energochłonnych, które bardzo silnie oddziałują na rozwój gospodarczy Polski, zarówno w sposób bezpośredni, jak i pośredni (poprzez stymulowanie innych branż przemysłu) w bardzo krótkim czasie może doprowadzić do trwałego spadku ich produkcji, co następnie przełożyć się może na spadek dochodów budżetowych z tytułu podatków dochodowych i podatku od towarów i usług, wzrost bezrobocia, spadek konsumpcji oraz stopy oszczędności gospodarstw domowych. Przypomnieć natomiast należy, że celem systemu EU ETS (zgodnie z postanowieniami dyrektywy) jest zapewnienie ograniczenia wielkości emisji gazów cieplarnianych w określonych sekInstytut Ochrony Środowiska, Krajowy Administrator Systemu Handlu Uprawnieniami do Emisji (KASURE), Zjawisko ucieczki emisji w sektorach energochłonnych w Polsce w kontekście zmian wprowadzanych w systemie EU ETS na lata 2013-2020, Warszawa, sierpień 2009, s. 9 i n.

Dyrektywa 2003/87/WE Parlamentu Europejskiego i Rady z dnia 13 października 2003 r. ustanawiająca system handlu przydziałami emisji gazów cieplarnianych we Wspólnocie oraz zmieniająca dyrektywę Rady 96/61/ WE (Dz.Urz. UE L 273/32 z dnia 25.10.2003 r.).

$\mathrm{Na}$ temat unijnej polityki klimatycznej np. M. Mehling, K. Kulovesi, J. de Cendra, Climate law and policy in the European Union: accidential success or deliberate leadership?, [w:] E.J. Hollo, K. Kulovesi, M. Mehling (red.), Climate Change and the Law, Dordrecht 2013, p. 519 and n. 
torach gospodarki w sposób ekonomicznie efektywny. ${ }^{7}$ Wdrażanie tego instrumentu powinno zatem odbywać się z uwzględnieniem wszystkich trzech elementów koncepcji zrównoważonego rozwoju (ochrona środowiska przy jednoczesnym zapewnieniu rozwoju społecznego i gospodarczego).

\section{Obecne regulacje prawne umożliwiające redukcję kosztów energii w przemyśle energochłonnym}

W obecnie obowiązującym polskim porządku prawnym istnieją jedynie pojedyncze (niewiele w praktyce znaczące) instrumenty wsparcia dla branż energochłonnych w postaci białych certyfikatów oraz mechanizmu naliczania opłaty jakościowej.

Głównym celem ustawy z dnia 15 kwietnia 2011 r. o efektywności energetycznej $^{8}$ wdrażającej dyrektywę 2006/32/WE Parlamentu Europejskiego i Rady z dnia 5 kwietnia 2006 r. w sprawie efektywności końcowego wykorzystania energii i usług energetycznych oraz uchylająca dyrektywę Rady 93/76/EWG (która z dniem 4 czerwca 2014 r. zostanie uchylona przez dyrektywę Parlamentu Europejskiego i Rady 2012/27/UE z dnia 25 października 2012 r. w sprawie efektywności energetycznej, zmiany dyrektyw 2009/125/WE i 2010/30/UE oraz uchylenia dyrektyw 2004/8/WE i 2006/32/WE ${ }^{10}$ ) jest poprawa efektywności energetycznej oraz promowanie innowacyjnych technologii, które zmniejszają szkodliwe oddziaływanie sektora energetycznego na środowisko. Na podstawie tego aktu prawnego wprowadzony został najnowszy system certyfikatów efektywności energetycznej. Tzw. białe certyfikaty wydawane są przez Prezesa Urzędu Regulacji Energetyki (URE) na projekty, które prowadzą do zmniejszenia zużycia energii.

Zgodnie z art. 13 ust. 1 ustawy o efektywności energetycznej odbiorca końcowy, który w roku poprzedzającym rok realizacji obowiązku uzyskania i przedstawienia do umorzenia Prezesowi URE świadectwa efektywności energetycznej lub uiszczenia opłaty zastępczej: 1) zużył nie mniej niż 400 GWh energii elektrycznej i 2) dla którego udział kosztu energii elektrycznej w wartości produkcji jest nie mniejszy niż 15\% - który zakończył nie wcześniej niż w dniu 1 stycznia 2011 r. przedsięwzięcie służące poprawie efektywności energetycznej, które nie dotyczy instalacji objętych systemem handlu uprawnieniami do emisji (...), ograniczając zużycie energii elektrycznej w przeliczeniu na wielkość produkcji, o nie mniej niż 1\% rocznie w stosunku do średniej jego wielkości z lat 2008-2010, przedstawia jednemu przedsiębiorstwu energetycznemu sprzedającemu temu odbiorcy energię elektryczną oświadczenie o zrealizowaniu przedsięwzięcia służącego poprawie efektywności

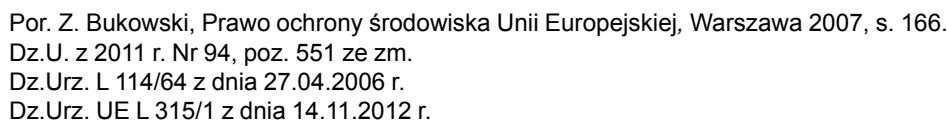


energetycznej wraz z audytem efektywności energetycznej (...) potwierdzającym osiągniętą oszczędność energii.

Przy czym w myśl art. 3 pkt 6 ustawy o efektywności energetycznej pojęcie odbiorcy końcowego należy definiować zgodnie z art. 3 pkt 13a ustawy z dnia 10 kwietnia 1997 r. Prawo energetyczne, ${ }^{11}$ czyli jest nim odbiorca dokonujacy zakupu paliw lub energii na własny użytek; do własnego użytku nie zalicza się energii elektrycznej zakupionej w celu jej zużycia na potrzeby wytwarzania, przesylania lub dystrybucji energii elektrycznej (w znaczeniu dyrektywy 2006/32/WE oraz dyrektywy 2012/27/ UE „odbiorca końcowy” oznacza osobe fizyczna lub prawna, która dokonuje zakupu energii do własnego użytku). Energia zużywana ,na własny użytek” to m.in. energia zużywana przez przedsiębiorstwo na potrzeby o charakterze administracyjnym, jak również do zasilania własnych instalacji służących do zużycia końcowego energii (np. zużywana wewnątrz zakładu na cele produkcyjne). Energia może zostać zakupiona „na użytek własny” lub „do dalszej odsprzedaży”.

Zgodnie z postanowieniami Drugiego Krajowego planu działań efektywności energetycznej z dnia 17 kwietnia 2012 r. (sporządzanego na podstawie art. 6 ust. 1 ustawy o efektywności energetycznej) system białych certyfikatów wspiera inwestycje w przedsięwzięcia energooszczędne, takie jak: modernizacja budynków, lokalnych sieci ciepłowniczych i źródeł ciepła, urządzeń przeznaczonych do użytku domowego, izolacja instalacji przemysłowych oraz odzyskiwanie energii w procesach przemysłowych. ${ }^{12}$ Wśród innych działań, które zostały przewidziane w Drugim Krajowym planie działań wylicza się programy wsparcia Funduszu Termomodernizacji i Remontów, a także programy wdrażane przez Narodowy Fundusz Ochrony Środowiska i Gospodarki Wodnej, w postaci dotacji lub preferencyjnych kredytów, dofinansowujące zadania inwestycyjne prowadzące do oszczędności energii w przedsiębiorstwach.

Konieczność dostosowania polskich regulacji do rozporządzenia Parlamentu Europejskiego i Rady nr 714/2009 z dnia 13 lipca 2009 r. w sprawie warunków dostępu do sieci w odniesieniu do transgranicznej wymiany energii elektrycznej i uchylające rozporządzenie $\mathrm{nr}$ 1228/2003, ${ }^{13}$ spowodowała uchwalenie nowego rozporządzenia Ministra Gospodarki z dnia 18 sierpnia 2011 r. w sprawie szczegółowych zasad kształtowania i kalkulacji taryf oraz rozliczeń w obrocie energią elektryczną. ${ }^{14}$ Wprowadzone zmiany służące skorygowaniu mechanizmów naliczania niektórych rodzajów stawek i opłat wynikały z praktyki stosowania poprzedniego rozporządzenia z zakresu tej problematyki. Nowe zasady naliczania jednej ze składowych ceny dystrybucji, a mianowicie opłaty jakościowej, mają istotne zna-

Tekst jedn. Dz.U. z 2012 r., poz. 1059 ze zm.

Drugi Krajowy plan działań dotyczący efektywności energetycznej, przyjęty przez Radę Ministrów dnia 17 kwietnia 2012 r., Ministerstwo Gospodarki, Warszawa, kwiecień 2012 r., s. 36-37.

Dz.Urz. UE L 211/15 z dnia 14.08.2009 r.

Dz.U. z 2011 r. Nr 189, poz. 1126. 
czenie z punktu widzenia przedsiębiorstw branży energochłonnej. W myśl postanowień $\S 25$ ust. 2 rozporządzenie Ministra Gospodarki z dnia 18 sierpnia 2011 r. przedsiębiorstwa będące odbiorcami końcowymi mogą zredukować koszty z tytułu opłaty jakościowej o 90\% pod warunkiem, że spełnią łącznie trzy kryteria: 1) zużywają w roku kalendarzowym poprzedzającym o rok dany rok kalendarzowy, w którym jest stosowana stawka jakościowa nie mniej niż 400 GWh energii elektrycznej; 2) wykorzystują nie mniej niż 50\% mocy przyłączeniowej oraz 3) dla których koszt energii elektrycznej stanowi nie mniej niż $15 \%$ wartości produkcji.

\section{Projektowane mechanizmy wsparcia umożliwiające redukcję kosztów energii w przemyśle energochłonnym}

Polscy przedsiębiorcy działający w branżach energochłonnych ponoszą obecnie wysokie koszty wynikające $\mathrm{z}$ funkcjonowania $\mathrm{w}$ polskim porządku prawnym systemu wsparcia wytwarzania energii elektrycznej z OZE oraz produkcji energii elektrycznej w wysokosprawnej kogeneracji. W projekcie ustawy o odnawialnych źródłach energii z dnia 4 października $2012 \mathrm{r} \cdot{ }^{15}$ przewidziane zostały uproszczenia dla przedsiębiorców działających w sektorach przemysłu energochłonnego, co ma w efekcie spowodować przyspieszenie optymalnego i racjonalnego wykorzystania OZE (w pkt 6 uzasadnienia zawarte zostały Propozycje szczególowych rozwiazań systemowych redukujacych koszty wynikajace $z$ polityki fiskalnej $i$ energetycznej $w$ grupie przedsiębiorstw energochtonnych). Problematyka sektora energochłonnego została również podjęta w projekcie (nowej) ustawy Prawo energetyczne z dnia 8 października 2012 r. ${ }^{16}$ (pkt 8 ).

W uzasadnieniach obu projektów ustaw (odpowiednio pkt 8 i 6) przypomina się, że w ostatnich kilku latach koszty związane z energią elektryczną stały się jednym z głównych czynników decydujących o konkurencyjności polskiego przemysłu i atrakcyjności inwestycyjnej Polski. Obserwowany w Polsce od 2006 r. gwałtowny wzrost cen produkowanej energii elektrycznej doprowadził do ich zrównania z poziomem notowanym w państwach tzw. UE- 15 . Równolegle rosły też koszty systemu wsparcia rozwoju energetyki odnawialnej i skojarzonej powiększane o jedną z najwyższych w UE akcyzę od energii elektrycznej. W tej sytuacji o zróżnicowaniu kosztów produkcji w obrębie UE zaczęła decydować polityka energetyczna i fiskalna państwa. Systemy wsparcia rozwoju energetyki odnawialnej i skojarzonej w Polsce w obecnym kształcie nie biorą pod uwagę wpływu rosnących kosztów energii na konkurencyjność polskich producentów. Realizacja polskiej polityki energetycznej środkami pochodzącymi z zakładów przemysłowych w sytuacji, gdy w innych państwach członkowskich UE branże energochłonne kosztów polityki energetycznej 
i fiskalnej nie ponoszą, prowadzi do utraty konkurencyjności polskiego przemysłu i wewnętrznej (w obrębie UE) carbon leakage.

Podkreśla się, że unijne normy prawne zawarte w dyrektywie Parlamentu Europejskiego i Rady 2009/28/WE z dnia 23 kwietnia 2009 r. w sprawie promowania stosowania energii ze źródeł odnawialnych zmieniająca i w następstwie uchylająca dyrektywy 2001/77/WE oraz 2003/30/WE ${ }^{17}$ oraz w dyrektywie Parlamentu Europejskiego i Rady 2004/8/WE z dnia 11 lutego 2004 r. w sprawie promowania kogeneracji w oparciu o zapotrzebowanie na ciepło użytkowe na rynku wewnętrznym energii oraz zmieniającej dyrektywę $92 / 42 / \mathrm{EW}^{18}$ nie przewidują minimalnych wymogów w odniesieniu do obciążenia poszczególnych uczestników rynku energii kosztami funkcjonowania systemu wsparcia wytwarzania energii elektrycznej z OZE oraz produkcji energii elektrycznej w wysokosprawnej kogeneracji. Problematyka dotycząca wprowadzenia przedmiotowego systemu wsparcia, zawarta w obu dyrektywach, została ujęta w sposób ogólny, co daje państwom członkowskim UE możliwość samodzielnego kształtowania zasad funkcjonowania krajowych systemów wsparcia. W Polsce natomiast energia elektryczna zużywana w przemyśle objęta jest pełnymi kosztami funkcjonowania systemów wsparcia, czyli podobnie jak energia wykorzystywana $\mathrm{w}$ innych procesach.

W związku z trwającym obecnie procesem zasadniczej przebudowy systemu prawa energetycznego projektuje się dla branż energochłonnych wprowadzenie redukcji obciążeń wynikających z obowiązku zakupu kolorowych certyfikatów. Zapowiadane regulacje prawne zmierzają na pewno do znacznego odciążenia przedsiębiorstw energochłonnych od ponoszonych kosztów funkcjonującego systemu wsparcia, ale nie wydają się być one jednak wystarczające w szczególności w kontekście ambitnej polityki klimatycznej UE.

Wdrożenie systemu redukcji obciążeń dla odbiorców przemysłowych spowoduje wprowadzenie do porządku prawnego pojęcia odbiorcy przemysłowego, którym będzie odbiorca końcowy, którego podstawową działalnością jest działalność gospodarcza $\mathrm{w}$ zakresie wydobywania węgla kamiennego lub rud metali nieżelaznych, produkcji wyrobów z drewna lub korka, z wyłączeniem produkcji mebli, produkcja papieru i wyrobów z papieru, produkcja chemikaliów i wyrobów chemicznych, produkcja wyrobów z gumy i tworzyw sztucznych, produkcja szkła i wyrobów ze szkła, produkcja ceramicznych materiałów budowlanych, produkcja metali (por. art. 2 pkt 31 projektu ustawy Prawo energetyczne). Podejście sektorowe w definicji odbiorcy przemysłowego związane jest ze zróżnicowaniem sektora energochłonnego w zakresie konkurencyjności i podatności na przenoszenie produkcji za granice Polski. 
Co więcej, w postanowieniach art. 69 ust. 1 projektu ustawy o odnawialnych źródłach energii oraz art. 138 ust. 1 projektu ustawy Prawo energetyczne została dokonana parametryzacja odbiorców przemysłowych, którzy z uwagi na energochłonność zostali zakwalifikowani do obniżenia kosztów funkcjonowania systemu wsparcia. Parametry charakteryzujące poszczególne kategorie przemysłowych odbiorców energochłonnych są tym wyższe, im mniejszy jest zakres ciążącego na nich obowiązku uzyskania i przedstawienia do umorzenia świadectw pochodzenia. Obniżenie kosztów wynikających z systemu wsparcia w oparciu o projektowane regulacje ma nastąpić zatem poprzez obniżenie podstawy obliczania wysokości obowiązku uzyskania i przedstawienia do umorzenia świadectw pochodzenia. Wprowadzony został maksymalny pułap obowiązku uzyskiwania i umarzania świadectw pochodzenia przez odbiorców energochłonnych, powyżej którego odbiorcy ci będą zwolnieni z obowiązku uzyskiwania i umarzania świadectw pochodzenia.

Ponadto przepisy art. 68 ust. 1 i 2 projektu ustawy o odnawialnych źródłach energii oraz art. 137 ust. 1 i 2 projektu ustawy Prawo energetyczne poszerzają (w porównaniu z obecnie obowiązującymi regulacjami) krąg podmiotów, który będzie mógł samodzielnie uzyskać i przedstawić do umorzenia Prezesowi URE odpowiednio świadectwo pochodzenia energii z OZE lub świadectwo wytworzenia energii w systemie kogeneracji, albo uiścić opłatę zastępczą o odbiorcę przemysłowego, który w roku kalendarzowym poprzedzającym rok realizacji obowiązku zużył nie mniej niż 100 GWh energii elektrycznej i dla którego koszt pozyskania energii elektrycznej wyniesie nie mniej niż 3\% wartości jego produkcji.

Projekt ustawy o odnawialnych źródłach energii wprowadza też nowe kategorie źródeł wytwórczych, tj. mikroinstalacje oraz małe instalacje (art. 2 pkt 14 i 15). Przewiduje również nowe rozwiązania w zakresie systemu wsparcia dla podmiotów inwestujących we własne źródła energii (m.in. zwolnienie z obowiązku uzyskania koncesji - art. 3; uproszczenia w zakresie przyłączenia mikroinstalacji do sieci dystrybucyjnej - art. 38 ust. 1 i art. 39 ust. 1; obowiązek zakupu energii po stałych i niezmiennych cenach - art. 41 i 42). Produkcja energii elektrycznej w miejscu jej zużycia ma szereg zalet istotnych zarówno dla zakładów przemysłowych, jak i Krajowego Systemu Elektroenergetycznego. Przemysłowa generacja rozproszona powoduje redukcję kosztów odbiorcy przemysłowego, ale również obniża koszty inwestowania w energetykę systemową. ${ }^{19}$ Zakłady przemysłowe budują własne źródła energii elektrycznej w celu poprawy konkurencyjności krajowych producentów i utrzymania miejsc pracy. 


\section{Podsumowanie}

Polscy przedsiębiorcy energochłonni zmuszeni są prowadzić swoją działalność w o wiele gorszych warunkach, niż ich konkurenci z innych państw członkowskich UE. ${ }^{20}$ System wsparcia energii wytwarzanej z OZE oraz energii produkowanej w systemie kogerencji znacząco obciążają kosztami polski przemysł energochłonny, co ogranicza np. możliwości inwestowania w przemysłowe źródła energii (z powodu wyprowadzenia z przemysłu do energetyki systemowej znacznych środków) i pogorsza konkurencyjność zakładów przemysłowych na rynkach globalnych i w obrębie UE, stwarzając wręcz zagrożenie dla dalszego funkcjonowania szczególnie tych najbardziej energochłonnych. ${ }^{21}$

W obecnie obowiązującym polskim porządku prawnym istnieją jedynie pojedyncze (niewiele w praktyce znaczące) instrumenty wsparcia dla branż energochłonnych. Projektowane w nowym prawie energetycznym regulacje zmierzają na pewno do znacznego odciążenia przedsiębiorstw energochłonnych od ponoszonych kosztów funkcjonującego systemu wsparcia, ale nie wydają się być one jednak wystarczające w szczególności w kontekście ambitnej polityki klimatycznej UE, która może spowodować wyhamowanie inwestycji i innowacji w tych obszarach, a także przyśpieszyć zjawisko tzw. ucieczki emisji.

Istnieje zatem pilna potrzeba rewizji obecnej polityki fiskalnej i energetycznej państwa wobec sektora przedsiębiorstw energochłonnych tak, aby mogły one łagodnie przechodzić do gospodarki niskoemisyjnej. Dla poprawy konkurencyjności branż energochłonnych niezbędne są kompleksowe rozwiązania systemowe, uwzględniające wszystkie kwestie mające wpływ na cenę energii elektrycznej, takie jak np. koszty przesyłu i dystrybucji oraz koszty wsparcia rozwoju energetyki odnawialnej i skojarzonej w kontekście szeroko pojętej efektywności energetycznej, redukcja zapotrzebowania na polecenie OSP, redukcja obciążeń fiskalnych, wprowadzenie ulg podatkowych (np. ulgi podatkowe dla firm inwestujących we własne źródła energii). Zwolnienie od akcyzy dla energii elektrycznej zużywanej w zakładach energochłonnych jest stanem wysoko pożądanym i od dawna postulowanym w Polsce. ${ }^{22}$ Postulaty te znajdują uzasadnienie w szczególności w konieczności przestrzegania zasady równości wobec prawa - odmienne traktowanie różnych wyrobów energetycznych jest niedopuszczalne, zaburza konkurencyjność polskich przedsiębiorców w UE. Zasady uczciwej konkurencji wymagają, aby w tym obszarze doprowadzić do harmonizacji rozwiązań funkcjonujących w Polsce i w większości państw członkowskich UE.

20 K. Badyda, Uwarunkowania emisyjne energetyki jako skutek wdrożenia regulacji unijnych, [w:] M. Rudnicki, K. Sobieraj (red.), Nowe prawo energetyczne, Lublin 2013, s. 42.

H. Kaliś, Czy przemysł jest..., op. cit., s. 36.

22 Interpelacja z dnia 1 lipca 2012 r. nr 6520 do Prezesa Rady Ministrów w sprawie stale pogarszającej się sytuacji zakładów zaliczanych do tzw. grupy energochłonnych wobec braku działań polskiego rządu zmierzających do obniżenia podatku akcyzowego od energii elektrycznej, dostępna na stronach www.sejm.gov.pl 
Istnieje też konieczność wprowadzenia w najbliższych latach dla branż przemysłu wysoce energochłonnego dopłat, równoważących koszty zakupu zezwoleń na emisję CO2 w szczególności biorąc pod uwagę, że obciążenia wynikające z funkcjonowania systemu EU ETS będą dla polskiego przemysłu rosnące z każdym kolejnym rokiem. Niestety, w Polsce w chwili obecnej brak jest nawet projektu przepisów w zakresie mechanizmów wsparcia dla zakładów energochłonnych. Nie ma też decyzji odnośnie tego, jak zostaną wykorzystane środki uzyskane z tytułu zakupu uprawnień CO2, nie wiadomo także, czy przedsiębiorstwa energochłonne będą uprawnione do otrzymania rekompensat z tytułu ponoszonych kosztów. Polskie Ministerstwo Gospodarki, w ramach prowadzonych obecnie prac nad Narodowym Programem Rozwoju Gospodarki Niskoemisyjnej, dopiero analizuje te kwestie. ${ }^{23}$

Jedynie silny i konkurencyjny przemysł oznacza silną i stabilną gospodarkę, miejsca pracy dla polskich obywateli, szansę na rozwój sektora usług oraz małych i średnich przedsiębiorstw, wreszcie gwarancję stabilizacji przychodów budżetowych nawet w czasach kryzysu gospodarczego.

\section{BIBLIOGRAFIA}

Badyda K., Uwarunkowania emisyjne energetyki jako skutek wdrożenia regulacji unijnych, [w:] M. Rudnicki, K. Sobieraj (red.), Nowe prawo energetyczne, Lublin 2013.

Baran J., Janik A., Ryszko A., Handel emisjami w teorii i praktyce, Warszawa 2011.

Bukowski Z., Prawo ochrony środowiska Unii Europejskiej, Warszawa 2007.

Drugi Krajowy plan działań dotyczący efektywności energetycznej, przyjęty przez Radę Ministrów dnia 17 kwietnia 2012 r., Ministerstwo Gospodarki, Warszawa, kwiecień 2012 r.

Dyduch J., Handel uprawnieniami do emisji zanieczyszczeń powietrza, Warszawa 2013.

Hollo J., Kulovesi K., Mehling M. (red.), Climate Change and the Law, Dordrecht 2013.

Instytut Ochrony Środowiska, Krajowy Administrator Systemu Handlu Uprawnieniami do Emisji (KASURE), Zjawisko ucieczki emisji w sektorach energochłonnych w Polsce w kontekście zmian wprowadzanych w systemie EU ETS na lata 2013-2020, Warszawa, sierpień 2009.

Instytut Ochrony Środowiska, Krajowy Administrator Systemu Handlu Uprawnieniami do Emisji (KASURE), Zjawisko ucieczki emisji w sektorach energochłonnych w Polsce w kontekście zmian wprowadzanych w systemie EU ETS na lata 2013-2020, Warszawa, sierpień 2009.

Interpelacja z dnia 1 lipca 2012 r. nr 6520 do Prezesa Rady Ministrów w sprawie stale pogarszającej się sytuacji zakładów zaliczanych do tzw. grupy energochłonnych wobec braku działań polskiego rządu zmierzających do obniżenia podatku akcyzowego od energii elektrycznej.

Kaliś H., Czy przemysł jest zainteresowany generacją rozproszoną?, [w:] J. Rączka, M. Swora, W. Stawiany (red.), Generacja rozproszona w nowoczesnej polityce energetycznej - wybrane problemy i wyzwania, Warszawa 2012. 
Mehling M., Kulovesi K., de Cendra J., Climate law and Policy in the European Union: accidential success or dedeliberate leadership?, [w:] E.J. Hollo, K. Kulovesi, M. Mehling (red.), Climate Change and the Law, Dordrecht 2013.

Projekt ustawy o odnawialnych źródłach energii z dnia 4 października 2012 r., wersja 2.0.1.

Projekt ustawy Prawo energetyczne z dnia 8 października 2012 r., wersja 1.24.

Rączka J., Swora M., W. Stawiany (red.), Generacja rozproszona w nowoczesnej polityce energetycznej - wybrane problemy i wyzwania, Warszawa 2012.

Rudnicki M., Sobieraj K. (red.), Nowe prawo energetyczne, Lublin 2013.

Założenia do Narodowego Programu Rozwoju Gospodarki Niskoemisyjnej przyjęte przez Radę Ministrów w dniu 16 sierpnia $2011 \mathrm{r}$. 


\section{CURRENT AND PLANNED MEANS OF SUPPORT ENABLING COST REDUCTION IN ENERGY-CONSUMING SECTORS OF INDUSTRY IN THE CONTEXT OF THE EU EMISSIONS TRADING SYSTEM}

The aim of addressing the subject area presented in the article, is to analyze national legal regulations with regard to both the current and planned means of support enabling cost reductions in the energy-consuming sectors of industry to be achieved. It should be pointed out that the burdens following implementation of the third phase of the EU Emissions Trading System, will increase annually. A wide range of support for national industry, especially during times of recession, might well contribute to increasing the competitiveness of Polish entrepreneurs both within and outside the EU. Conversely, a lack of proper state support particularly for the energy-consuming sectors of industry which contribute significantly to Poland's economic development could well lead to a decrease in production output and a consequent downturn of the state budget, the latter by way of reduced revenue income from taxes, unemployment growth and decline in domestic consumption.

Keywords: EU Emissions Trading System, energy-consuming sector, energy effectiveness 